E3S Web of Conferences 1, 10001 (2013)

DOI: $10.1051 / \mathrm{e} 3$ sconf/20130110001

(c) Owned by the authors, published by EDP Sciences, 2013

\title{
Seasonal dynamics of microbial mercury transformations in sediments and water column of Gulf of Trieste (northern Adriatic Sea)
}

\author{
N. Koron ${ }^{1,2}$, A. Bratkič ${ }^{3}$, S. Ribeiro Guevara ${ }^{4}$, T. $\operatorname{Tinta}^{5}$, K. Klun ${ }^{6}$, J. Faganeli ${ }^{7}$ and M. Horvat ${ }^{8}$ \\ ${ }^{1}$ National Institute of Biology, Marine Biology Station, Fornače 41, 6330 Piran, Slovenia, koron@mbss.org \\ ${ }^{2}$ Department of Environmental Sciences, 'Jožef Stefan' Institute, Jamova 39, 1000 Ljubljana, Slovenia, \\ neza.koron@ijs.si \\ ${ }^{3}$ Department of Environmental Sciences, ‘Jožef Stefan’ Institute, Jamova 39, 1000 Ljubljana, Slovenia, \\ arne.bratkic@ijs.si \\ ${ }^{4}$ Laboratiorio de Análisis por Activación Neutrónica, Centro Atómico Bariloche, Av. Bustillo km 9.5, 8400 Bariloche, \\ Argentina, ribeiro@cab.cnea.gov.ar \\ ${ }^{5}$ National Institute of Biology, Marine Biology Station, Fornače 41, 6330 Piran, Slovenia, tinta@mbss.org \\ ${ }^{6}$ National Institute of Biology, Marine Biology Station, Fornače 41, 6330 Piran, Slovenia, klun@mbss.org \\ ${ }^{7}$ National Institute of Biology, Marine Biology Station, Fornače 41, 6330 Piran, Slovenia, faganeli@mbss.org \\ ${ }^{8}$ Department of Environmental Sciences, ‘Jožef Stefan' Institute, Jamova 39, 1000 Ljubljana, Slovenia, \\ milena.horvat@ijs.si
}

\begin{abstract}
A series of relatively simple incubation experiments to assess and evaluate microbial mercury (Hg) transformations in water column and sediments were performed monthly or bimonthly in a period from March 2011 to December 2011. Sampling campaigns were performed at station F in the southeastern part of Gulf of Trieste, northern Adriatic Sea. Gulf of Trieste has been for the last 500 year continuously impacted with inflow of $\mathrm{Hg}$, originating from the Idrija $\mathrm{Hg}$ mine. The microbial mercury transformations were assessed using a short-lived $\left(\mathrm{t}_{1 / 2}=64.12 \mathrm{~h}\right)$ radioisotope ${ }^{197} \mathrm{Hg}$. Calculated activities of microbial $\mathrm{Hg}$ reduction and methylation were correlated with other environmental factors, such as temperature, nutrient availability, oxygenation, organic matter, substrate ( $\mathrm{Hg}$ in bioavailable chemical form) availability, structure of microbial community and presence of mer operon. Preliminary results show that in water column a substantial $\mathrm{Hg}$ reduction occurs, whereas methylation was not observed. On the other hand, long-term incubation experiments with sediments show that methylation process is active however preliminary results also suggest a significant $\mathrm{MeHg}$ degradation.
\end{abstract}

Key words: mercury, microbial transformation, water column, sediments, radiotracer

\section{Introduction}

Mercury $(\mathrm{Hg})$ and it species have been recognized as one of the most potent environmental pollutants. $\mathrm{Hg}$, especially monomethylmercury $(\mathrm{MeHg})$ has a tendency to accumulate in aquatic food webs and can through fish consumption pose a risk also to human population.

Biogeochemistry of $\mathrm{Hg}$ is very complex and has been thoroughly studied for the last three decades. During this time main actors, biotic as well as abiotic, that drive transformations of $\mathrm{Hg}$ have been mainly recognized (Compeau and Bartha, 1985; Kerin et al., 2006), however it has yet to be accurately assessed how and to what extent do microbial transformations in water column contribute to global $\mathrm{Hg}$ budget.

Gulf of Trieste (northern Adriatic Sea) is one of shallow marine environments that have been greatly subjected to continuous input of $\mathrm{Hg}$. For the last 500 years it is being carried from the second largest $\mathrm{Hg}$ mine in the world (Idrija Hg mine) to the Gulf by the river Soča /Isonzo.

At a research station $\mathrm{F}$ in the Southeastern part of the Gulf in a period from March 2011 to November 2011 montly and bimonthly sampling campaigns were performed. Sediments and water samples were used in rather long-term incubation experiments using radioisotope ${ }^{197} \mathrm{Hg}$ to assess microbial methylation and reduction activities. It is well known that different factors 
influence these processes, so the importance of most of them (temperature, nutrient availability, oxygenation, organic matter, $\mathrm{Hg}$ bioavailability, structure of microbial community and presence of mer operon) was also investigated in this study.

\section{Materials and Methods}

The study site was located $2.3 \mathrm{~km}$ off Cape Madona (Piran, Slovenia) in the southeastern part of Gulf of Trieste where also Slovenian hydrographic buoy Vida is located. Water column depth in this part of the Gulf does not exceed $22 \mathrm{~m}$.

For each experiment the water samples were collected from three different depths using a rosette of Niskin bottles. Two depths were constant, $1 \mathrm{~m}$ bellow surface $(1 \mathrm{~m})$ and $1 \mathrm{~m}$ above sediment $(21 \mathrm{~m})$, whereas intermediate depth was chosen after an examination of CTD profile. Based on the hypothesis of this work, the depth of choice displayed the highest values of chlorophyll $a(\mathrm{Chl} a)$ or when this criterion was not met (there was no maximum), the samples were collected in the middle of thermocline. Sediment cores were collected at the same site using gravity corer.

In the laboratory, cores used for conventional $\mathrm{Hg}$ speciation analyses were extruded and cut into $1 \mathrm{~cm}$ thick slices in a $\mathrm{N}_{2}$-filled glove bag and afterward centrifuged to extract pore waters. These were then filtered, acidified and frozen until analyses. Sediments devoid of pore were also frozen.

Sediments for incubation experiments were sectioned in only two slices $(0-2 \mathrm{~cm}$ and $2-4 \mathrm{~cm})$ and transferred into acid pre-cleaned and autoclaved $100 \mathrm{ml}$ glass bottles (Schott Duran).

To accurately follow the dynamics of microbial transformations in water and sediment samples, radiotracer ${ }^{197} \mathrm{Hg}$ was used. Its applicability has already been described (Ribeiro Guevara et al., 2007; Žižek et al., 2008) and highlighted for these kind of experiments (Koron et al., 2012).

This short-lived radioisotope $\left(\mathrm{t}_{1 / 2}=64.12 \mathrm{~h}\right)$ was produced from enriched $(52 \%){ }^{196} \mathrm{Hg}$ stable isotope in TRIGA Mark II $(250 \mathrm{~kW})$ research nuclear reactor of the 'Jozef Stefan' Institute in Ljubljana, Slovenia (Snoj et al., 2011).

Water samples for tracer experiments were transferred to acid pre-cleaned glass bottles and amended with radiotracer to a final concentration of $8 \mathrm{ng} \mathrm{L}^{-1}$. ${ }^{197} \mathrm{Hg}^{0}$ produced in water column was lead to traps containing $\mathrm{KMnO}_{4}$. The amount of ${ }^{197} \mathrm{Hg}^{0}$ collected was determined on a daily basis (app. every $24 \mathrm{~h}$ ) using a well type HPGe (High Purity Germanium) detector (Canberra Industries Inc., USA). Total ${ }^{197} \mathrm{Hg}$ values were also determined on a daily basis.

Since the methylation activity in water column is expected to be low, the determination of $\mathrm{Me}^{197} \mathrm{Hg}$ was conducted every other day. The extraction of $\mathrm{Me}^{197} \mathrm{Hg}$ from samples was done by an organic solvent extraction (Liang et al., 1996) with an additional step using
DOWEX ion exchange resin to remove any residual ${ }^{197} \mathrm{Hg}$ (II). All values obtained were corrected for nuclear decay (Ribeiro Guevara et al., 2007) and finally the activities were calculated.

Sediment samples were only measured for $\mathrm{Me}^{197} \mathrm{Hg}$ production. Extraction was done by solvent extraction (Liang et al., 1996) also using additional step with DOWEX.

To determine not only the activities of microbial transformations but also to identify the key environmental factors that influence the ongoing transformations, samples for conventional $\mathrm{Hg}$ analyses and all other ancillary analyses, i.e. for nutrient concentrations in water column, Corg/Ntot in sediments and samples for determination of microbial community and presence of mer operon were also collected and analysed.

\section{Results and Discussion}

\section{Sediments}

A series of analyses were performed in the sediments sampled, including $\mathrm{C}_{\text {org }}$ and $\mathrm{N}_{\text {tot }}$ analyses (data not shown), $\mathrm{THg}$ and $\mathrm{MeHg}$ and $\mathrm{THg}$ and $\mathrm{MeHg}$ in pore waters (data not shown). Figure 1 and Figure 2 show the concentrations of $\mathrm{THg}$ and $\mathrm{MeHg}$, respectively, in sediments of the Gulf during the period of study. It can be seen that $\mathrm{THg}$ values range from 150 to $220 \mathrm{ng} \mathrm{g}_{\mathrm{dw}}^{-1}$, with upper layers exhibiting the lowest values in summer and autumn months.

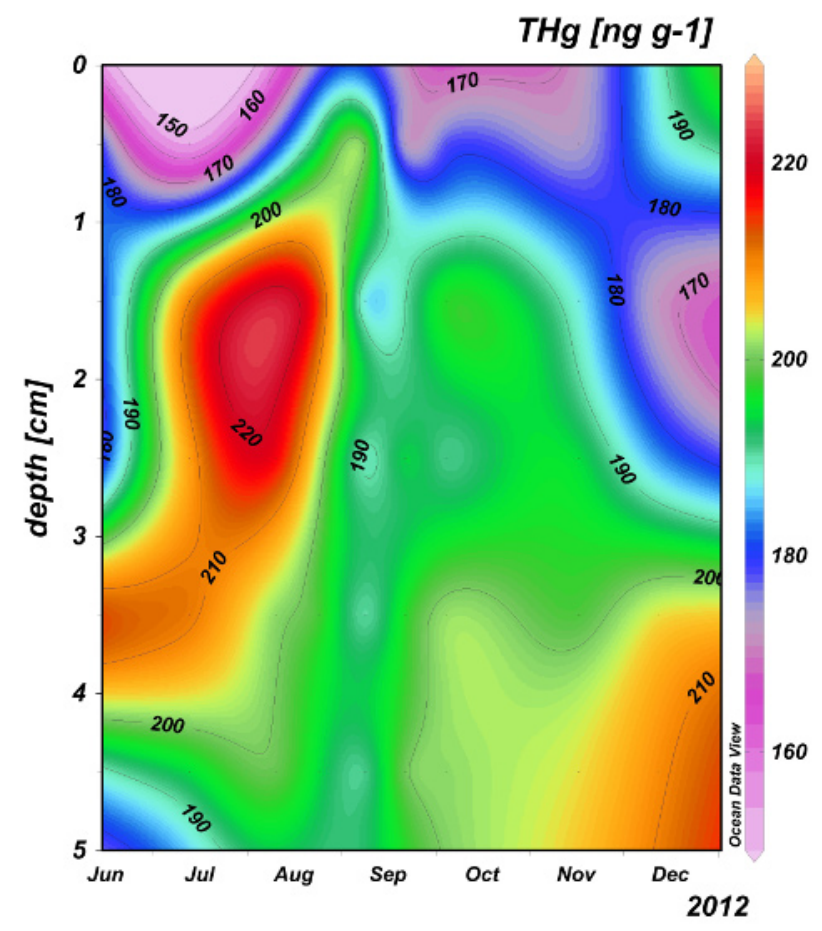

Fig. 1. THg values in sediments of Gulf of Trieste at station $\mathrm{F}$ in period from June to December, 2011

$\mathrm{MeHg}$ values (Figure 2) range from 0.2 to $0.7 \mathrm{ng} \mathrm{g}^{-}$ ${ }_{\mathrm{dw}}$ with the lowest values coinciding with $\mathrm{THg}$ values. Values observed might be a consequence of a significant 
benthic outflow from the sediment into the overlying water due to enhanced solubility of $\mathrm{Hg}$ species in these circumstances (Hines et al., 2012).

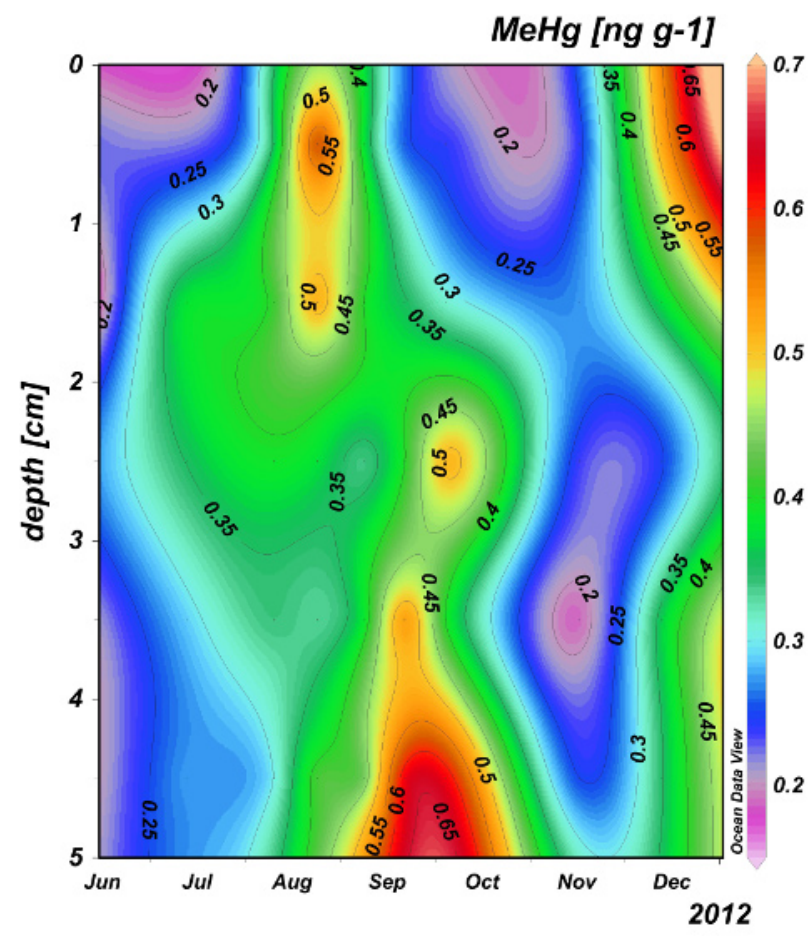

Fig. 2. $\mathrm{MeHg}$ concentrations in sediments of Gulf of Trieste at station $\mathrm{F}$ in a period from June to December, 2011

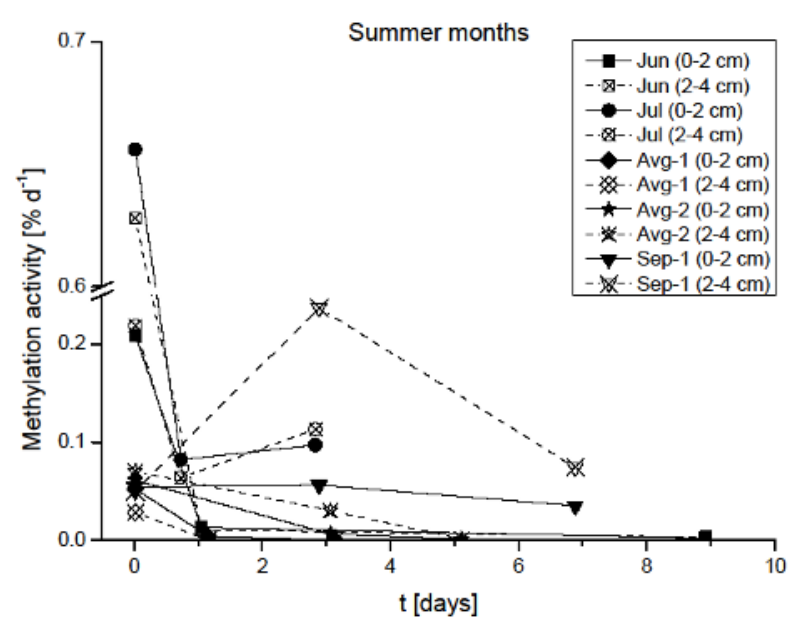

Fig. 3. Methylation activities in sediment in summer months (note the scale)

Activities reported here are first rate constants $\left(\% \mathrm{~d}^{-}\right.$ $\left.{ }^{1}\right)$ and represent a percentage of radioisotope ${ }^{197} \mathrm{Hg}$ transformed to observed species during a period of 24 hours. Measured methylation activities show a significant 'flash' methylation, assessed $30 \mathrm{~min}$ after spiking of sediments. Since incubation experiments altogether lasted from 3 to 9 days, they are considered as long-term incubation experiments, showing a net $\mathrm{Hg}$ methylation. Measured $\mathrm{Me}^{197} \mathrm{Hg}$ concentrations are thus a result of two simultaneously occurring opposing processes, methylation and demethlyation. On the other hand 'flash' methylation is a measure for gross methylation.

Our results are consistent with results published by Hines et al. $(2000,2012)$ who determined net methylation rates of $0.5-1 \% \mathrm{~d}^{-1}$ for the Gulf. Demethylation activities in sediments of the Gulf and nearby Grado and Marano Lagoons exceed methylation activities up to 6 times, which explains why the calculated methylation activities drop during the experiment.

\section{Water column}

The aim of this part of the study was to assess the activities of microbial transformations in water column. $\mathrm{Hg}$ methylation was not observed, whereas reduction activities proved to be quite high. Here only the results gained from samples taken at intermediate depth are shown, since this depth was of primary interest.

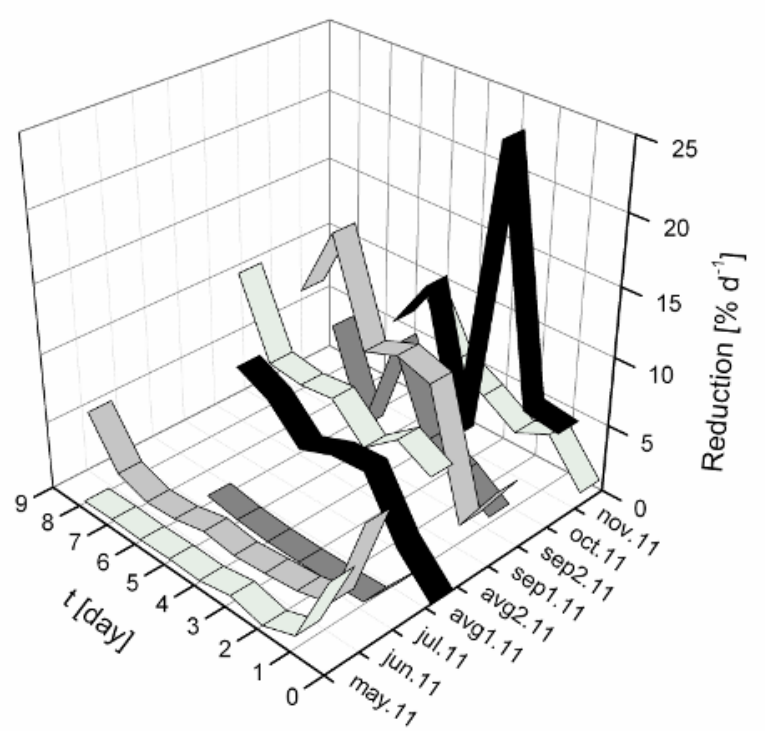

Fig. 4. Reduction activity in water column at intermediate depth

Since the experiments were conducted in glass bottles, the photoreduction of $\mathrm{Hg}$ can be excluded therefore the observed reduction is a result of activity of heterotrophic bacteria and phytoplankton.

The results show increasing reduction activity in intermediate depth from beginning to late summer. In the second half of September activity drops and remains relatively constant also in October and November, with maximum at day 3 in October experiment. It must be emphasized that this intermediate depth was not fixed, but varied from $6 \mathrm{~m}$ to $18 \mathrm{~m}$, depending on current environmental factors. All the samples except two in September and one in October were chosen based on the highest Chl $a$ contents in water.

The other important difference between these samples is the temperature (the incubation temperature was the same as temperature of the sea at the time of 
sampling), which has important influence on microbial metabolism.

During the period from May to late September the biomass of heterotrophic bacteria, which actually play the vital role in $\mathrm{Hg}$ transformations in water column (Barkay et al., 2003) is also increasing, and remain high even in October and November and also later, when an autumn phytoplankton bloom occurs (data not shown). Currently any other definite conclusions are impossible since the samples for determination of microbial community and presence of mer operon are yet to be analyzed.

\section{Conclusion}

Methylation activities in sediments have proven to be quite high, however these rather long-term incubation experiments indirectly point to even more active demethylation process, occurring simultaneously.

Methylation in water column was not detected, however the reduction activity seems to be quite high and comparable to activities found by Monperrus et al. (2007). Any definite conclusions are currently avoided, but preliminary data show very actively reducing microbial population.

It was again shown that radioisotope ${ }^{197} \mathrm{Hg}$ is a valuable tool for assessing the rates of $\mathrm{Hg}$ transformations in different environmental samples. Nevertheless, the usage of this isotope is more convenient for short-term experiment since the need for constant correction for nuclear decay is this way omitted.

\section{Acknowledgements}

The authors would like to thank the whole Sagita crew for their help with sampling.

\section{References}

Barkay T, Miller SM, Summers AO. Bacterial mercury resistance from atoms to ecosystems. Fems Microbiology Reviews 2003; 27: 355-384.

Compeau GC, Bartha R. Sulfate-reducing bacteria: Principal methylators of mercury in anoxic estuarine sediment. Applied and Environmental Microbiology 1985; 50: 498-502.

Hines ME, Horvat M, Faganeli J, Bonzongo J-CJ, Barkay
T, Major EB, et al. Mercury biogeochemistry in the Idrija River, Slovenia, from above the Mine into the Gulf of Trieste. Environmental Research Section A 2000; 83: 129-139.

Hines ME, Poitras EN, Covelli S, Faganeli J, Emili A, Žižek S, et al. Mercury methylation and demethylation in $\mathrm{Hg}$-contaminated lagoon sediments (Marano and Grado Lagoons, Italy). Estuarine Coastal and Shelf Science 2012: 1-11.

Kerin EJ, Gilmour CC, Roden E, Suzuki MT, Coates JD, Mason RP. Mercury methylation by dissimilatory iron-reducing bacteria. Applied and Environmental Microbiology 2006; 72: 7919-7921.

Koron N, Bratkič A, Ribeiro Guevara S, Vahčič M, Horvat M. Mercury methylation and reduction potentials in marine water: An improved methodology using ${ }^{197} \mathrm{Hg}$ radiotracer. Applied Radiation and Isotopes 2012; 70: 46-50.

Liang L, Horvat M, Cernichiari E, Gelein B, Balogh S. Simple solvent extraction technique for elimination of matrix interferences in the determination of methylmercury in environmental and biological samples by ethylation gas chromatography cold vapor atomic fluorescence spectrometry. Talanta 1996; 43: 1883-1888.

Monperrus M, Tessier E, Amouroux D, Leynaert A, Huonnic P, Donard OFX. Mercury methylation, demethylation and reduction rates in coastal surface waters of the Mediterranean Sea. Marine Chemistry 2007; 107: 49-63.

Ribeiro Guevara S, Žižek S, Repinc U, Perez Catan S, Jaćimović R, Horvat M. Novel methodology for the study of mercury methylation and reduction in sediments and water using ${ }^{197} \mathrm{Hg}$ radiotracer. Analytical and Bioanalytical Chemistry 2007; 387: 2185-2197.

Snoj L, Trkov A, Jaćimović R, Rogan P, Žerovnik G, Ravnik M. Analysis of neutron flux distribution for the validation of computational methods for the optimization of research reactor utilization. Applied Radiation and Isotopes 2011; 69: 136-141.

Žižek S, Ribeiro Guevara S, Horvat M. Validation of methodology for determination of the mercury methylation potential in sediments using radiotracers. Analytical and Bioanalytical Chemistry 2008; 390: 2115-2122. 